\title{
Disputing 'market value': the Bombay Improvement Trust and the reshaping of a speculative land market in early twentieth-century Bombay
}

\author{
Dr Shabnum Tejani, SOAS University of London
}

\begin{abstract}
Urban expansion in the early twentieth century had a profound impact on India's urban land economies. Historians argue that in this period, urban India went through an increasing marketization of land and that improvement trusts had a significant hand in accelerating land speculation. In the case of Bombay, we still understand little of the relationship between the activities of the Bombay Improvement Trust and rising land values. The paper examines key legal disputes around compensation for land acquired by the Trust for public purpose before and after the First World War. Such cases show how the Trust and the judiciary shaped changing expectations around what comprised 'market value' and consequently became deeply involved in Bombay's land economy. Where officials had earlier resisted valuations that they believed encouraged speculation, after the 1920s the resolution of disputes incorporated future value as a legitimate and necessary part of the economy.
\end{abstract}


On 30 January 1905, the Special Collector of the City of Bombay Improvement Trust awarded Merwanji Muncherji Cama and his brother Hormusji the amount of just over five lakh rupees (Rs 512,105). ${ }^{1}$ The award was for land acquired under the Land Acquisition Act of 1894 for a goods depot in the neighbourhood of Chinchpooghly, Byculla, for the Great Indian Peninsular Railway. The amount was to compensate the 'market value' of land, in this case, four plots totalling 85,799 square yards. At well over eight lakh rupees (Rs 837,780), the Cama brothers' surveyors differed considerably from the collector in their valuation. Their calculations employed a method which took into account the potential value of the land, if developed with buildings. In contrast, the collector had calculated an amount based on the rent it could raise in its current condition. In March, after a tribunal confirmed the original award, the brothers declared it to be 'opposed to the received rules of law, equity and good conscience' and appealed to the Bombay High Court. ${ }^{2}$

The Cama brothers' case opens a window onto Bombay's rapidly expanding land economy in the early twentieth century. With increasing numbers of individuals investing in land and large swathes being acquired for development, disputes abounded as to how its value should be calculated. The officers of the Trust and the judges of the High Court resisted calculations based on projections of what land might be worth in the future, arguing that it encouraged speculation. Yet by the 1920s, their valuations reflected the speculative logic of the market.

This article examines this shift towards speculative valuation. It explores land valuation in an important moment of Bombay's expansion. Cities in colonial India witnessed a period of rapid growth in the early twentieth century as rural populations migrated to work in new industries. Improvement trusts were established in several cities to manage the task of urban development, Bombay's being the first in 1898. Trusts acquired land through the Land Acquisition Act of 1894 to build roads, housing for the working classes and transport systems to settle suburbs. Industrialization and urban growth had a significant impact on India's urban land economies. In Bombay, land values rose, prompting spiralling rents and speculation. Historians argue that in this period, urban India went through an increasing marketization of

\footnotetext{
${ }^{1}$ Maharashtra State Archives (MSA), Legal Department, Suits, Bombay B-1/1 1907-10, compilation no 116 of 1907, Reference in the Matter of Merwanji Muncherji Cama and another vs. The Government of Bombay; 9 Bombay Law Reporter (henceforth Bom LR) 1232 (1907), In re: Land Acquisition Act, 1894, In re: Government of Bombay and Merwanji Muncherji Cama.

2 'Land acquisition, railway goods depot', Times of India, 28 Nov. 1906.
} 
land. Prashant Kidambi, among others, argues that the Bombay Improvement Trust had a significant hand in accelerating speculation in urban land. ${ }^{3}$ That land speculation accompanies urban expansion is part of liberal economic common sense - we take for granted the relationship between urban growth and speculation. ${ }^{4}$ However, we still understand little of what this relationship looked like in modern South Asia.

There is a growing literature on speculation in the South Asian context. We know that speculative practices have a long history in India. Ritu Birla has explored a range of such practices from rain gambling to betting on commodities such as jute, opium and silver in western, northern and eastern India. She argues that 'market governance' sought to tame the rather wild - and illegitimate - element of chance in the gamble, with legal devices that, by the early twentieth century, had separated gambling from speculation. ${ }^{5}$ The history of speculation in urban land, however, is understudied, with a few recent exceptions. Debjani Bhattacharyya, for instance, shows in her study of Calcutta how, around the 1920s, debates in official circles separated the 'economicity of speculation' in land from the 'criminality of rent profiteering', with the former central to a forward-looking economy. ${ }^{6}$ Similarly, Anish Vanaik's study of Delhi in the early twentieth century demonstrates the significance of the colonial state's interventions and the interests of business houses in shaping the city's land markets through the 1930s and 1940s. ${ }^{7}$ In its examination of the forces shaping land markets in colonial India, this scholarship challenges the inevitability of the relationship between urbanisation and speculation and deepens our understanding of how capitalism develops in specific contexts.

This article examines the role of the Trust in land speculation in early twentiethcentury Bombay. In particular, it looks at key legal disputes around land valuation before and after the First World War. Cases of valuation and compensation are important in understanding this moment in Bombay's urban history as they shine a light on the way that

\footnotetext{
${ }^{3}$ P. Kidambi, The making of an Indian metropolis: colonial governance and public culture in Bombay, 18901920 (Aldershot, Hants, 2007).

${ }^{4}$ A. Haila, Urban land rent: Singapore as a property state (Oxford, 2016).

${ }^{5}$ R. Birla, Stages of capital: law, culture and market governance in late colonial India (Durham NC, 2009), chapter 4 .

${ }^{6}$ D. Bhattacharyya, 'Interwar housing speculation and rent profiteering in colonial Calcutta', Comparative Studies of South Asia, Africa and the Middle East (CSSAAME), 36 (2016), 465-82 at 480.

${ }^{7}$ A. Vanaik, Possessing the city: property and politics in Delhi, 1911-1947 (Oxford, 2019).
} 
the Trust sought to manage challenges around compensation. As judgements in such disputes make clear, there was no objective value in land that officers of the Trust could establish. Indeed, the article argues that far from being neutral bodies seeking to determine an accurate value to the land, the Trust and the judiciary were important actors in shaping ideas about what the proper methods of land valuation were and thus, the land market itself. Rulings on disputes in the 1920s marked a shift away from the earlier resistance to speculative valuation to a point where future value was incorporated as a legitimate, even necessary, part of the economy. The article begins with a background to Bombay's land economy and the work of the Trust before going into a discussion of the Land Acquisition Act and its definition of market value. It then explores a series of cases in the Bombay High Court around methods of valuation from 1905 to 1926.

\section{Urban land in Bombay before the Trust}

Bombay is a city that came into being in the period of British rule. The East India Company took over the islands of Bombay from Charles II in $1661 .{ }^{8}$ It established its base in the southern tip which it fortified, an area still called 'Fort', encouraging migration and settlement in its attempt to turn Bombay into a centre of trade and enterprise. By the late eighteenth century, its settled population had grown to about $100,000 .{ }^{9}$ Bombay had numerous tenurial systems dating back to early medieval Hindu dynasties, which made it difficult to determine accurately what revenue had to be paid to the government. Land revenue surveys sought to clarify the complex of rights and entitlements and transform certain forms of tenure into freehold plots. ${ }^{10}$ An Act of 1839 recognized 'private interests' in land, marking the beginning of efforts to systematize land administration and the transfer and exchange of properties. Officials sought to acquire land for the development of the city, in particular for the railways, from what had now become private owners. ${ }^{11}$

Bombay's economy grew rapidly through the nineteenth century and it replaced Surat as the primary commercial hub in western India. The cotton and opium trade attracted

\footnotetext{
${ }^{8}$ M. Dossal, Theatre of conflict, city of hope: Mumbai 1600 to present times (New Delhi, 2010), 4-13.

${ }^{9}$ Ibid., 34-6.

${ }^{10}$ Ibid., 42-4, 72 passim.

${ }^{11}$ Ibid., 108. On land acquisition in the early colonial state, see D. Bhattacharyya, 'History of eminent domain in colonial thought and legal practice', Economic and Political Weekly, 50 (2015), 45-53.
} 
merchants, largely from the Hindu and Muslim Gujarati trading castes, as well as Parsis. ${ }^{12}$ The Great Indian Peninsular Railway and Bombay, Baroda and Central India Railway companies began operations in the $1850 \mathrm{~s}$, opening up the cotton growing districts in the Deccan. The first cotton mills were opened in 1854 and drew large numbers of migrant labourers from the surrounding countryside. ${ }^{13}$ The cotton boom of the 1860 s spurred industrial growth and commodity speculation. Land reclamation was also underway by the 1860s under the auspices of the new Government of India. Vast tracts of land were reclaimed from the western and eastern foreshores, managed by companies which made enormous profits in the period of economic expansion. ${ }^{14}$

The city was transformed through the nineteenth century as new land was created. In the late nineteenth century, the government began efforts to convert Bombay's 'complex system of tenures into straightforward and saleable plots', a process that Mariam Dossal argues 'made possible the transition from a nascent to a full-fledged capitalist land market'. ${ }^{15}$ The development of the commercial district and the Port Trust drew more migrants to the city, increasing the demand for housing. Land prices rose, and, as Sandip Hazareesingh argues, 'investment in urban real estate provided lucrative new opportunities' for those who had made their fortunes in cotton and opium. ${ }^{16}$ Indeed, as Chandavarkar notes, anyone who could, invested in land during this period. ${ }^{17}$ The new landlords built commercial properties and private chawls which were often cheaply constructed, cramped and lacking drainage and sewage connections. Mill owners and merchants built new mills and chawls in Byculla, Parel, Tardeo and Worli in the north of the city, and the greatest number of new migrants settled here. By the turn of the twentieth century, Bombay was increasingly an industrial city marked by 'environmental degradation, human poverty and health pandemics'. ${ }^{18}$ The outbreak of the

\footnotetext{
${ }^{12}$ C. Dobbin, Urban leadership in Western India: politics and communities in Bombay City, 1840-1885 (Oxford, 1972), chapter 1.

${ }^{13} \mathrm{R}$. Chandavarkar, The origins of industrial capitalism in India: business strategies and the working classes in Bombay 1900-1940 (Cambridge, 1994), chapter 4.

${ }^{14}$ M. Dossal, Imperial designs and Indian realities: the planning of Bombay City, 1845-1875 (Delhi, 1991), chapter 6 .

${ }^{15}$ Dossal, Theatre of Conflict, 133.

${ }^{16} \mathrm{~S}$. Hazareesingh, The colonial city and the challenge of modernity: urban hegemonies and civic contestations in Bombay City, 1900-19251925 (Hyderabad, 2007), 16.

${ }^{17}$ Chandavarkar, Origins, 175-7.

${ }^{18}$ Hazareesingh, Colonial City, 23-5.
} 
bubonic plague and growing awareness of this urban crisis was the context for the creation of the Improvement Trust in 1898.

\section{The Bombay Improvement Trust}

The plague caused widespread disruption in the city, claiming over 100,000 lives, almost 14 per cent of the city's population. ${ }^{19}$ Many others fled for their villages in the surrounding countryside. The poorer sections of the city - the old town and the mill areas - suffered most. Officials believed that the plague was spread through crowded, squalid conditions. Thus, the Trust was established to proffer solutions to what was seen as the problem of urban overcrowding. It was given the task of 'improving' the city - by creating new roads and neighbourhoods, clearing slums and providing housing for the working classes. It was to drain swamps, reclaim land from the sea and create new areas for the wealthy classes, as well as prepare for the city's expansion north. It did so through a series of planned 'schemes': the first sought to create a neighbourhood with tenement housing and sanitary facilities in one of the poorest and most congested areas, Nagpada. The next two were road building schemes that opened out a path from the business district in the Fort to make an easy commute for the richer classes who had moved west to Malabar Hill and its surrounding areas. ${ }^{20}$

The Trust was given land owned by the government of Bombay and the city's municipal corporation with the idea that it could be developed and leased out. The government had also transferred reclamation rights in some parts of the western coast of Bombay to the Trust with the same idea. ${ }^{21}$ It was within the Trust's jurisdiction to acquire privately-owned land 'for public purpose'. The schemes all involved the acquisition of land from people with varying entitlements to it. While the earlier schemes reshaped the city that already existed, the later schemes sought to bring new land into being, from which were created the new suburbs to the north - Dadar, Matunga and Worli - as well as the exclusive

\footnotetext{
${ }^{19}$ S.M. Edwardes, Census of India 1901, Bombay (Town and Islands), parts IV, V and VI, vols. 10 and 11 (Bombay, 1901).

${ }^{20}$ On the Bombay Improvement Trust, see Kidambi, Indian Metropolis, chapter 4; Hazareesingh, Colonial City, chapter 1; Dossal, Theatre of Conflict, chapter 7.

${ }^{21}$ Kidambi, Indian Metropolis, 74-5. In Bombay city the government of Bombay acquired land on behalf of the Improvement Trust: see F. G. Hartnell Anderson, Manual of land acquisition for the Presidency of Bombay (Bombay, 1918), India Office Records (IOR), British Library, (BL), 1.
} 
enclaves of Cuffe Parade and Colaba to the south. ${ }^{22}$ In a short span of time, the Trust acquired enormous amounts of land. By 1915, its estates accounted for 10 per cent of all urban land and, by 1925, 20 per cent, making it the single largest landowner in the city. The land it acquired would be laid out into plots to be leased normally for 99 or 999 years, in line with the practice around real property in Britain. ${ }^{23}$ Similar trusts were established in other cities in the early twentieth century, notably Calcutta (1911), Hyderabad (1912) and later Delhi (1937). ${ }^{24}$

Historians note rising rents and land values during this period and suggest a close relationship between these and the activities of the trusts. Prashant Kidambi and Sandip Hazareesingh have argued that in Bombay, the Trust increased competition for land which fuelled speculation. ${ }^{25}$ In Calcutta, Debjani Bhattacharyya notes that in the practice of land acquisition, the Calcutta Improvement Trust 'effectively fashioned itself as a land developer in the city'. ${ }^{26}$ Despite these insights, we still have little understanding of the forces that shaped land values and speculation in urban South Asia. In Bombay, the special officer would determine the compensation to be awarded to the tenants or owners. Landholders were entitled to challenge the award, which many did, and disputes turned on the methods by which those amounts had been reached. ${ }^{27}$ Acquisition officers emphasized that land had an intrinsic value. Yet, determining what that was often proved complicated and contentious. ${ }^{28} \mathrm{It}$

\footnotetext{
${ }^{22}$ On schemes to develop Dadar and Matunga, see N. Rao, House, but no garden: apartment living in Bombay's suburbs, 1898-1964 (Minneapolis MN, 2013). On the Cuffe Parade, Backbay and Colaba reclamation projects, see G. Prakash, Mumbai fables (Princeton, 2010), chapter 3.

${ }^{23}$ C.A. Webb and N.A. Webb, Valuation of real property: a guide to the principles of valuation of land and buildings, etc. for various purposes (London, 1937).

${ }^{24}$ E. L. Beverley, 'Urbanist expansions: planner-technocrats, patrimonial ethics and state development in Hyderabad', South Asia: Journal of South Asian Studies (henceforth South Asia), 36 (2013), 375-96; Bhattacharyya, 'Interwar housing speculation', 469-70; A. Vanaik. 'Representing commodified space: maps, leases, auctions and "narrations" of property in Delhi, c. 1900-47', Institute of Historical Research (2014) DOI: 10.1111/1468-22081. The Indian trusts were modelled on urban development projects in Britain such as the Glasgow Improvement Trust: see S. Hazareesingh, 'Colonial modernism and the flawed paradigms of urban renewal: uneven development in Bombay, 1900-25', Urban History, 28 (2001), 235-55.

${ }^{25}$ Kidambi, Indian Metropolis, 88; Hazareesingh, 'Colonial modernism', 241.

${ }^{26}$ Bhattacharyya, 'Interwar housing speculation', 469-70.

${ }^{27}$ For use of the Land Acquisition Act of 1894 elsewhere, see D. A. Johnson, 'Land acquisition, landlessness, and the building of New Delhi', Radical History Review, 108 (2010), 91-116.

${ }^{28}$ Hartnell Anderson, Manual, 38.
} 
became quickly clear that officers' attempts to determine land values proved elusive at best. Any idea that there was an objective value to land was defeated. Let us now turn to considering rising land values in the early years of the Improvement Trust.

\section{The Improvement Trust and rising land values}

The Trust's board had fourteen members comprised of colonial officials and local elites, many of whom were landowners themselves. ${ }^{29}$ Its development plans were viewed with some suspicion by the existing administrative and commercial bodies in the city. There was particular tension between the Trust and the municipal corporation when the prominent businessmen and landlords of the city who made up the corporation questioned the financial wisdom of its schemes. ${ }^{30}$ Nevertheless, the Trust began its operations in 1898. It immediately embarked on large-scale demolition of housing in the city's most congested areas, displacing tens of thousands of the urban poor with inadequate provision for rehousing. ${ }^{31}$ The local press, aghast at the housing situation, roundly criticised the Trust, accusing it of favouring rich areas over poor. As one item in the Gujarati noted, the "main concern of the Trust would be the improvement of the insanitary areas of the city and the provision of well-lighted and well-ventilated residential quarters for the poor inhabitants'. Yet the Trustees 'think it necessary to construct a fine marine drive along Kennedy Seaface....They were never appointed to look to the...wants of fashionable folks before attending to questions of vital importance to the population at large'. ${ }^{32}$

The pressure on housing led to rapidly increasing rents. Hazareesingh notes that between 1898 and 1918 rents increased between 100 and 200 per cent. ${ }^{33}$ A report commissioned on the development of Bombay published in 1914 gathered opinion from officials, engineers and businessmen in the city who suggested the rising rents and land prices

\footnotetext{
${ }^{29}$ These included three ex-officio trustees; seven elected trustees of whom four were elected by the Municipal Corporation, one by the Bombay Chamber of Commerce, one by the Port Trust of Bombay and one by the Bombay Millowners Association; and three trustees and a chairman nominated by the Government of Bombay. See Rao, House But No Garden, notes to chapter 1, note 8, 248.

${ }^{30}$ Hazareesingh, Colonial City, 31-2, Kidambi, Indian Metropolis, 84-5.

${ }^{31}$ On the housing crisis created by the Trust, see P. Kidambi, 'Housing the poor in a colonial city: the Bombay Improvement Trust, 1898-1918', Studies in History, 25 (2001), 57-79.

${ }^{32}$ Native Newspaper Reports for the Bombay Presidency (NNRBP), Gujarati, 28 Apr. 1901.

${ }^{33}$ Hazareesingh, Colonial City, 43-4.
} 
were closely connected to the activities of the Trust. ${ }^{34}$ In his statement to the committee, Abdul Hoosein Adamji Peerbhoy, a Bohra businessman, wrote that the Trust's demolition of housing had displaced large numbers of the city's poor and increased congestion and insanitary conditions in other areas. Significantly, he noted, fewer houses 'had helped to increase rents and consequently the value of landed properties in Bombay'. ${ }^{35}$ Many also believed that the Trust's new houses, built with the more expensive materials of cement and steel, were meant for a richer class of tenant. ${ }^{36}$ However, the problem was as much that spiralling rents encouraged speculation, a concern for officials as well as a wider public. The collapse of a new building in Crawford Market in 1903 drew angry criticism from those who believed that because of high land prices, a 'class of capitalists' had sprung up in the city, 'building cheap houses' and making 'big fortunes with reckless disregard for the safety of the tenants who may live therein'. ${ }^{37}$ H.P. Mody, the Special Officer to the Committee for the Development of Bombay, warned that the Trust's acquisitions had 'drawn into the market speculative builders'. ${ }^{38} \mathrm{He}$ contended that while the areas to the north of the city should be developed, 'private owners of land should not be allowed to buy up large areas and sit tight over them for years waiting for a rise in the market'. Speculation should be carefully managed through 'well-considered enactments governing the acquisition and assessment of land in the future'. 39

Yet the Trust itself was criticised for engaging in 'speculative transactions'. ${ }^{40}$ The Ratepayers' Association of Bombay argued that it was profiting from its own activities: it acquired properties as part of a scheme which it would then sell at enormous profit. A piece in the Jam-e-Jamshed noted that the Trust acquired plots 'in some of the best portions of town' and 'in a money-making craze' sold them off without consideration for building purposes. ${ }^{41}$ The Trust also drew censure from property owners who complained bitterly that it had been ruinous for them. Vasantrao Anandrao Dabholkar, in his statement to the

\footnotetext{
${ }^{34}$ Bombay Development Committee (Hill) Report, 1913-14, IOR, BL.

${ }^{35}$ Hill Report, submission from Abdul Hoosein Adamji Peerbhoy, 22 Nov. 1913, p. 86.

36 'Rents in Bombay', Times of India, 16 Aug. 1907. This is a point the chairman of the Trust himself attested

to: Hazareesingh, Colonial City, 44.

${ }^{37}$ NNRBP, Bombay Samachar, 2 June 1903.

${ }^{38}$ Ibid., H.P. Mody to the Special Officer to the Committee for the Development of Bombay, Hill Report, 125-7.

${ }^{39}$ Ibid., 127.

${ }^{40}$ NNRBP, Bombay Samachar, 21 Aug. 1902.

${ }^{41}$ NNRBP, Jam-e-Jamshed, 23 Jan. 1903.
} 
development committee, observed that landlords had 'suffered heavy losses'. The Trust, he complained, would 'notify' properties and then sit for years without actually acquiring them, a move which prevented landlords from selling to private owners. ${ }^{42}$ In urban India, there was a tendency for landlords deliberately to keep their rents low so as to avoid municipal rates. When the Trust began its acquisitions in Bombay, however, many quickly raised their rents so in the event of the land being notified they would get close to its actual value. ${ }^{43}$ It was, Dabholkar noted, the Trust's 'acquisition procedure' that was the problem. In the north of the island, it demolished existing buildings, turning the land into a vacant space to be laid out in plots with roads running in between. It had paid very little for the land acquired for Dadar, Matunga and Sion, and later 'succeeded in selling [a plot] at a value twice as high as the price awarded'. ${ }^{44}$ The notification and acquisition of land had created great uncertainty, he claimed. The Trust had, the Bombay Samachar held, tended to 'unsettle the value of house property in the city'. ${ }^{45}$

\section{Land Acquisition and the 'Market Value' of Land}

Tenants and owners whose land had been notified were to be compensated its 'market value' as outlined in section 23 of the Land Acquisition Act of 1894. The act outlined the principles for compensation according to English law. In calculating the award, officers were to take into account a number of principles: the loss or injury sustained by the interested person deprived of their land, the value to the owner and the 'potential value' of the land. The 'value to the owner' was different than the 'market value', and was defined as 'the value which a willing seller may expect from a willing purchaser in the open market' ${ }^{46}$ The 'potential value' calculated the value of what the land would be worth if put to a particular purpose which enhanced its value. If the potential value was properly determined, this could be its market value.

\footnotetext{
${ }^{42}$ Hill Report, submission from Vasantrao Dabholkar, 28 Nov. 1913, 106-8.

${ }^{43}$ Ibid. See too: Kidambi, Indian Metropolis, 86-7.

${ }^{44}$ Hill Report, Dabholkar submission, 108.

${ }^{45}$ NNRBP Bombay Samachar, 30 June 1903.

${ }^{46}$ M.N. Gupta, Land acquisition acts and principles of valuation (Calcutta, 1939), 126-9.
} 
The definition of 'market value' was vague, and was taken to mean 'the price a willing buyer would give to a willing seller' ${ }^{47}$ It could be determined by considering the price of similar property in the neighbourhood at the time of notification or by its potential future disposition if laid out in the most lucrative manner. ${ }^{48}$ Actual sales of similar lands in the locality were deemed to give 'an index of the proper market value' but did not, by themselves, stand in for it. ${ }^{49}$ Further to complicate matters, the Indian courts also recognised three other methods of determining market value: 1) the price paid in bona fide transactions, that is, in an unforced sale; 2) capitalization, a calculation that involved a projection usually over 25 years, which took into account an estimation of depreciation to the land and buildings, a deduction for the costs for developing the land, the ground rent and the projected interest from the rent; and 3) expert opinion, the opinion of valuators and experts who used both recent sales and capitalisation of land revenue to calculate the land's value. ${ }^{50} \mathrm{In}$ England, valuers tended to favour capitalisation as a more 'scientific' method. ${ }^{51}$ In India, courts were inclined to give preference to sales of the land itself or of similar lands in the neighbourhood, as in many parts of Bombay, land was being laid out for the first time. In either context, sales had to be bona fide or else they would not give a proper market value. It was the basis on which market value was to be determined that arguments in court turned.

In the case of the Cama brothers, the land that had been acquired was for a goods depot in the industrial area in the Indian town. The collector's award had been calculated on the 'net rental' method. This involved calculating the net income through rent of the acquired land and buildings, multiplying it by a certain number of years to give a figure that was supposed to reflect the current value of the land. ${ }^{52}$ The Cama brothers, however, had also had their land valued by the 'hypothetical' scheme and the valuation was almost one and a half times that of the collector. The hypothetical method held that if a parcel of land could be developed for more profitable future use, this may enhance its value and must be considered as a factor. So, it calculated the value of a parcel of land by providing figures of residential or

\footnotetext{
${ }^{47}$ Ibid., 132.

48 Ibid., 132-3.

49 Ibid., 135.

${ }^{50}$ Ibid., $135-6$.

${ }^{51}$ Ibid., 136.

${ }^{52}$ On the rental method and other methods of valuing land, see MSA, Public Works Department (PWD), file

'Lands: Bombay', vol. 333, compilation no. 50 of 1904 (1904-9); Kidambi, Indian Metropolis, 86-7.
} 
commercial buildings that might be built upon it. The number of units, the rent they may yield and the projected future demand were all taken into account. The net annual return was then capitalised. The value was hypothetical as it was based on a projected calculation of how the land might be developed and what rental income it may yield subsequently. ${ }^{53}$

The difference in the two approaches lay in the ambiguity around what constituted land value. The Land Acquisition Act prescribed that land had an intrinsic value. The Camas' position, also guided by the Act, maintained that the "potential value of the land must be taken into consideration'. ${ }^{54}$ Compensation, the Camas argued, should be based 'not [on] what the property is actually worth, but what a Bombay purchaser in a Bombay market would think it is worth and would give for it'. The land in question was in the centre of the mill district and had 'an inherent value for every possible purpose connected with mills'. It was, they insisted, 'extremely desirable from an investor's point of view'. ${ }^{55}$ They noted that between 1902 and 1904, the value of land had risen steeply in the mill district. The number of people working in the mills was growing quickly and demand for land was great. Any doubts about projecting a profit should be allayed. Counsel thus argued that the proper method of valuation would be through the hypothetical scheme, confirmed by sales in the neighbourhood. ${ }^{56}$ Valuing land in Bombay, however, was complicated by the inconsistency of tenures. As a result, Rao argues, the land market worked on a 'principle of proximity and adjacency' - land was valued in line with other plots in the vicinity. ${ }^{57}$ In the Cama case, the counsel for the government maintained that the hypothetical scheme had been misapplied. It was normally used to value land in a crowded locality meant for buildings. ${ }^{58}$ Yet, the Camas' land was meant only for mills and thus 'the value of the land would depend upon the

\footnotetext{
53 The hypothetical method is also explained in 10 Bom LR (1908) 907, Appeal from Original Civil, Government of Bombay v. Merwanji Muncherji Cama. For other disputes on the valuation of land acquired by the Land Acquisition Act 1894 in the first decade of the twentieth century, see: Indian Law Reports (I.L.R.) 33 Bom 483 (1909) The Trustees for the Improvement of the City of Bombay, v. Jalbhoy Ardeshir Sett and Another; I.L.R. 34 Bom 618 (1910), In the matter of the Land Acquisition Act of 1894, the Government of Bombay, v. Esufali Salebhai; I.L.R. 34 Bom 486 (1910) In the matter of Land Acquisition Act. In the matter of Government and Sukhanand Gurumukhrai and Another.

549 Bom LR (1907) 1232, In re: Government of Bombay and Merwanji Cama, 1236.

${ }^{55}$ Ibid.

${ }^{56}$ Ibid., 1237.

${ }^{57}$ Rao, House But No Garden, 35.

${ }^{58}$ I.L.R. 29 Bom (1905) 565, Anandrav Vinayak v. Secretary of State for India in Council and Another
} 
condition of the mill-industry'. ${ }^{59}$ At the time of notification the mill industry was at a low ebb, with unsecured ground rents on land with no buildings. Thus, there were no comparable buildings against which the sale could be checked.

There were other issues: the advocate general pointed out that the hypothetical value projected the volume of demand for the chawls that were planned to be built on the land. How was that to be verified? If the tenements to house those working in the mills were actually erected and occupied, then the collector would not dispute the calculation. But it was not clear that demand from such skilled workers existed. ${ }^{60}$ Moreover, demand could not be determined by offers of sales, for while sales had a 'probative value', they may not give a proper market value. ${ }^{61}$ A sale may be forced, or without proper enquiry by valuers, it may be to someone unreliable; it may not thus be 'genuine'. ${ }^{62}$ Hypothetical development thus presumed a level of demand that may not be there. ${ }^{63}$ In addition, there was the problem that offers of sales could simply spiral out of control, artificially inflating prices. The Trust baulked at the hypothetical valuation because it tended to higher amounts and had cost them dear. ${ }^{64}$ It also resisted equating land value with what people were willing to pay as it fuelled speculation. The judge in the Cama case deemed the rental method a more reliable determinant of market value as it reflected what the land would bring at that time. A hypothetical calculation, he said, had negligible basis in actual circumstances and the Camas had 'over built in imagination'. ${ }^{65}$ However, he noted, if a buyer is looking to sell on, the value of the property does not come from rents but from 'the future market price which he speculates on obtaining' ${ }^{66}$ A buyer will not buy the property if he does not believe he can recoup the costs of the transaction on resale and get more than the market price at the time of purchase.

It was the tension between these two approaches - the one asserting an objective value for land and the other insisting that value shifted with demand and circumstance - that

\footnotetext{
599 Bom LR (1907) 1236

${ }^{60} \mathrm{Ibid} ., 1246$

${ }^{61}$ Gupta, Land Acquisition Acts, 138.

${ }^{62}$ Ibid., 138-9.

${ }^{63}$ Ibid.

${ }^{64}$ Historians agree on this point. See Kidambi, Indian Metropolis, 87, and Rao, House But No Garden, 33.

659 Bom LR (1907)., 1251.

${ }^{66} \mathrm{Ibid} ., 1281$.
} 
shaped the Trust's approach to assessing market value. Yet, herein lay the problem, for how was market value to be objectively assessed? The Camas, wanting the best outcome for themselves, maintained that the recent history of rising prices in the area reflected the current value for chawls. The collector's offer was not accurate, their counsel alleged, for people were offering double the amount even on inferior plots removed from the main road. When buyers were willing to offer higher prices in the vicinity of the claimants' land, an earlier purchase price could not be taken as reflecting the market value. Counsel argued that land purchased at lower prices should be seen 'as an index rather of the minimum price at which land could be bought in that neighbourhood before the market had realised the potentialities of development' ${ }^{67}$ Thus the price at which land was sold did not necessarily indicate its true potential. Speculation drove value upwards and should figure in the calculation. Despite his reservations, the judge accepted the hypothetical scheme, saying that 'a hypothetical scheme can be open to no reproach... [if] based on ascertained facts'. ${ }^{68}$ The case went through the courts of appeal and reached the Privy Council, which ultimately upheld the judgement supporting the use of hypothetical valuation.

When tested in subsequent cases, however, the hypothetical scheme was found wanting. One case was that of Dhanjibhoy Bomanji in relation to the acquisition of two plots of land in 1904 in Mazagon, in the eastern part of the city near the P\&O dockyard. This was a mixed area. There was a koli (fishing community) settlement and a native Portuguese and Hindu community. The land was to be acquired by the Bombay Port Trust for the construction of a railway. ${ }^{69}$ Bomanji worked for the British India Company of the British Indian Dock, which were aiming to extend their land holdings westwards into the city. As their agent, he sought to acquire land and a number of properties in the area. The land would be used to house the displaced kolis and Bomanji anticipated it would increase in value because of the acquisition by the British India Company. ${ }^{70}$ The Collector's award used the hypothetical scheme and was based on the judgement that this was a 'dying locality', a suggestion that Bomanji challenged. Justice Macleod in the Bomanji case was scathing in his rejection of the scheme: 'an hypothetical building scheme ....depends on imaginary buildings

\footnotetext{
${ }^{67}$ Ibid., 1274

${ }^{68}$ Ibid., 1232.

69 The Port Trust, like the Improvement Trust, had the jurisdiction to acquire land for public purpose.

7010 Bom LR 701 (1907), In re: Dhanjibhoy Bomanji.
} 
fetching imaginary rents'. ${ }^{71}$ The method originated, he believed, when experts had to justify the high value they placed on land where there was no direct evidence for such values. The gross rents expected from buildings yet to be constructed were supposed to yield the market value. The problem was that, in determining rent, the valuer necessarily began with a 'preconceived opinion of the value of the land'. ${ }^{72}$ The hypothetical scheme's calculations were thus moulded around a value that had already been fixed. The judge determined that it was wrong 'to go further into the future and estimate the exact use to which the land may be put and the profit to be derived therefrom', for that calculation would be 'purely hypothetical and cannot possibly be based on ascertained facts'. ${ }^{73}$

As the hypothetical scheme came under scrutiny and was largely rejected for heavily inflated valuations and its tendency to speculation, the courts turned more regularly to other methods like comparative sales in the neighbourhood and a method known as 'plotting'. The latter was used for newly laid out areas in the suburbs where there was very little by way of comparable land to value it. ${ }^{74}$ Essentially, a potential purchaser would make an offer on a piece of land based on calculations that involved plotting the land out into building sites. A developer would calculate the costs of developing the land. In addition to the construction of buildings, this included filling, clearing and draining the land and creating infrastructure such as lighting and roads. Surveyors estimated what the plots would fetch once developed and after the costs were subtracted. The value of the separate plots when added together was supposed to yield the market value of the total area. A rather neat method, as Rao writes, this allowed the developer to 'demand retail prices for what amounted to a wholesale transaction'. ${ }^{75}$ Judges were also wary of plotting schemes, arguing that land had one value and land with buildings, another. Moreover, one judge warned: 'too much importance must not be attached to evidence of offers'. He cautioned against professional speculators: these were 'irresponsible brokers' who made offers 'on behalf of undisclosed principals' or for themselves with no principal behind them. These offers were 'useless' ${ }^{76}$

\footnotetext{
${ }^{71}$ Ibid., 705.

${ }^{72}$ Ibid.

${ }^{73}$ Ibid., 706.

${ }^{74}$ Rao, House But No Garden, 32-3.

${ }^{75}$ Ibid., 34.

${ }^{76} 10$ Bom LR 907 (1908), 908-9.
} 
By 1908 the hypothetical scheme was considered by the courts to be too speculative, over-estimating the market value of land. Yet neither offers nor plotting were viewed as an accurate gauge of land values. Significantly, judges made clear that valuation was not to be led by trends in the market. In a case of a piece of land belonging to Karim Tar Mahomed in Mazagon, notified in 1904, the judge observed that the valuation could not be based on what the property was producing at the time, nor had there been any recent sales of the land to go by ${ }^{77}$ Rather, the market value had to be determined 'by sales of similar land in the neighbourhood' ${ }^{78}$ The court could also be guided by the opinions of surveyors, although the judge determined that their reports must 'be based on facts and not on hypothesis'. ${ }^{79} \mathrm{He}$ maintained that it would not be difficult to arrive at approximate values for land on the Mazagon Road as six neighbouring plots had been bought and sold at around the same time as the plot under notification. The six plots went at auction for increasingly higher prices between 1902 and 1907: Rs 21 per square yard in 1902, Rs 37 per square yard in 1906, Rs 47 per square yard in 1907. The judge noted that 'there was nothing to show that land value had increased between 1902 and 1904' but pointed to the boom in the mill industry when 'from early in 1905 prices of land began to rise...until...by the end of the year almost fabulous prices were being given' ${ }^{80}$ He continued that sales after the notification in 1904 should be disregarded, 'when it is proved that values have been affected one way or the other by circumstances which have arisen after that date' ${ }^{81}$ The fluctuations of the market, then, must be kept out of the equation.

In the years before the War, officials of the Trust sought to compensate those from whom it had acquired land for purposes of urban development its 'market value'. Judges were wary of incorporating the rising land prices into their calculations, seeing them as inflated and speculative. The First World War saw a land boom across cities in British India, however, which had a significant impact on the valuation methods of the Trust and subsequent judgments in the High Court.

\footnotetext{
${ }^{77}$ ILR 33 Bom (1909) 325, In re: Land Acquisition Act cause in the matter of 1. Government of Bombay, 2. Karim Tar Mahomed.

${ }^{78}$ Ibid.

${ }^{79}$ Ibid., 328.

${ }^{80}$ Ibid.

${ }^{81}$ Ibid.
} 


\section{Land speculation after the War}

The end of the War brought significant economic change. Indian merchants and industrialists had prospered through the years of the First World War, with the immediate post-war period witnessing further growth in trade and industry. ${ }^{82}$ In urban India, trading communities invested their gains in commodities and machinery as well as in land. Ritu Birla and Debjani Bhattacharyya suggest that the expansion of the Indian economy in the early twentieth century saw a shift on the part of the colonial government to legitimize speculative investment as important for a modernizing economy. This seems to reflect broader changes in approaches to the economy in this period. Timothy Mitchell, writing on Egypt, argues that around the 1930s, there was a shift in how people - government officials, academics, policy makers - understood the economy. In a departure from earlier decades, he maintains that they began to refer to 'the economy' with a definite article, seeing it as an autonomous entity with universal principles. The economy now 'denoted a distinct social sphere', an object that could be studied scientifically. ${ }^{83}$

The end of the War also marked a significant change to the structures of colonial governance. In 1918 the government of India introduced the Montagu-Chelmsford reforms, a constitutional measure that devolved the day-to-day responsibility for governing to the provinces. Thus, irrigation and public works, education, land revenue administration, excise, industrial matters, police and such were now run from the provincial governments, and, significantly, were largely in Indian hands. This meant that the 'colonial state' looked quite different in 1920 than it had in 1905: there was often divergence in policy approaches between departments as well as differences of opinion with the centre of power in Delhi ${ }^{84}$ In addition, the Bombay Improvement Trust having been widely criticised for failing to improve the housing and sanitation conditions - indeed many argued it had exacerbated the problems of homelessness and overcrowding - was replaced in 1920 by the Bombay Development Directorate (BDD) which was to oversee the course of urban development in the city. The criticisms had come largely from the prominent landowners and businessmen of the city, some of whom comprised the municipal corporation and whose speculative ambitions the

\footnotetext{
${ }^{82}$ B.R. Tomlinson, The economic history of modern India from 1860 to the twenty-first century (Cambridge, 2013), 114-5.

${ }^{83}$ T. Mitchell, Rule of experts: Egypt, techno-politics, modernity (Berkeley CA, 2002), 73-4.

${ }^{84}$ On the introduction of Dyarchy, see S. Legg, 'Dyarchy: democracy, autocracy and the scalar sovereignty of interwar India', CSSAAME, 36 (2016), 44-65.
} 
Trust's valuations had presumably thwarted. The Trust continued in a minor role until 1933 when it was absorbed into the municipal corporation. ${ }^{85}$

In urban India the post-war economic boom brought new investment in Bombay's land market. Many investors became landlords and the high rents and squalid living conditions remained despite government attempts to introduce rent regulation in $1918 .{ }^{86}$ The Registration Department's annual report for 1918 already noted an extraordinary rise in the value of property in the city. Land registrations in 1919 showed a 64 percent increase in the aggregate value of transactions over the previous three years. ${ }^{87}$ The rise in land prices seemed to take many by surprise - people called it a 'frenzy', a 'madness' - and drew much angry commentary. The Trust received some of that ire, but most was reserved for those who had 'amassed wealth in some trade or speculation'. They were, one P. B. Joshi wrote, 'speculators in landed properties' from the mercantile classes of the city, 'the Bohras, Bhatias, Marwardis and Banias'. They bought properties at 'fabulous prices' and drove rents up in order to recoup the high prices they had paid for the land. Many had bought plots from the Trust and then sold them on at a profit to people who would sell them on again. ${ }^{88}$ Significantly, escalating land values attracted a wider net of investors than ever before. As one writer noted, 'the mad speculation in landed properties... had been indulged in not only by the rich, but also by those who were not rich'. ${ }^{89}$

The intensity of speculation had put real pressure on housing and people complained about greedy landlords who forced middle class families to squeeze into tiny spaces which bred squalor and immorality as they increased their income. ${ }^{90}$ Many called on the government to make 'profiteering' in land illegal. One letter in 1919 explained that the war had given speculators 'a powerful driving force. Tons of money has been amassed by profiteers who do not know what to do with their ill-gotten gains'. They put it into housing

\footnotetext{
${ }^{85}$ Kidambi, Indian Metropolis, 112; Rao, House But No Garden, 25-7.

${ }^{86}$ Hazareesingh, Colonial City, 105; V. Caru, 'Circumstantial adjustments: the colonial state, the nationalist movements and rent control legislation (Bombay, 1918-1928)', Le Mouvement Social, 1 (2013), 81-95.

${ }^{87}$ Registration Department Bombay Presidency, Annual Reports for 1918 and 1919, IOR, BL.

88 'Housing in Bombay: III Landlords and Tenants', P.B. Joshi, Times of India, 1 Aug. 1919.

89 'Rack-Renting in Bombay: A Protest Meeting', Times of India, 13 Mar. 1918.

90 'Housing in Bombay: the People's Hardship', Times of India, 12 Aug. 1919. Bania and Bhatia are caste names for Gujarati merchant, trading or money-lending communities. Marwaris are a trading caste from Rajasthan. Borahs are a Muslim trading community from Gujarat.
} 
and land and "pay fabulous sums for anything of the kind thrown their way.... Plots leased or sold by the Improvement Trust have been changing hands time after time, for prices bordering on the insane'. ${ }^{91}$ The Rent Enquiry Committee's report of 1939 confirmed this wider public concern. It commented that the increase in property values through the war was due to a shortage of housing, but equally to the 'speculative tendency... that is observable in the property market'. ${ }^{92}$ One witness from the Bombay Tenants Central Committee remarked that capital investment 'in landed property was a business proposition today for people with money had no other alternative'. The problem was that 'possession of landed property had become the monopoly of only a few individuals'. 93 'Frequent changes in... [property] ownership', the report continued, 'often result in an attempt to raise rents' ${ }^{94}$ Thus property speculators could not be relied upon to lower their rents, for 'capital that is attracted to building industry seeks increasing profits' ${ }^{95}$

The post-war land boom had a significant impact on the Trust and its practices of compensation. In a period of speculation where people were willing to offer far more than a piece of land was currently worth, how was its real value to be ascertained? How far should the Trust follow the trends of the market in its awards? A case concerning compensation for a piece of land notified in 1919, at the height of the boom, provides some insight into these questions. The land was part of the Trust's scheme 53, to develop Worli, a suburb in the north, with reinforced concrete chawls. The property was acquired in 1920 for about Rs 15 per square yard. On appeal, the Tribunal calculated its value at 19 percent above the award, at just over Rs.18 per square yard. How did they justify such a rise? The Trust's annual report for 1921 commented that, given the period of speculation,

the increase allowed by the Tribunal cannot be deemed to be excessive.... When the state of the market is uncertain, owing more to speculative rise, than to a genuine demand, it is difficult to estimate values that can be sustained in courts of law with

\footnotetext{
${ }^{91} \mathrm{Ibid}$.

${ }^{92}$ Report of the Rent Enquiry Committee (Bombay, 1939), vol. I, 31.

${ }^{93}$ Ibid., Oral Evidence, vol. III, 9-10.

${ }^{94}$ Ibid., vol. I, 31.

${ }^{95}$ Ibid., 34-8.
} 
any degree of certainty - more so when the speculative element is such as cannot altogether be excluded from a natural rise due to supply and demand. ${ }^{96}$

This acknowledgement that speculation should be incorporated into the compensation awards quickly became common practice. Citing a judgement made in 1920, the same report noted that calculations using the plotting scheme made 'no provision...for the original purchaser's profit at the time when he gets back this money. Supposing...he gets nothing for his troubles and for the risk that would be incurred', why would anyone enter the market on these conditions? Thus, the report stated, 'it is necessary to consider that a purchaser will expect to realise a larger profit on his original investment than the novel rate of interest so that...he will allow... an ample margin for his own profit'. ${ }^{97}$

The post-war land boom was over quickly and land values fell away steeply. The Registration Department recorded a declining number of deeds registered for immoveable property in Bombay after $1920 .{ }^{98}$ It attributed the large decrease in registrations to a 'reaction following a period of abnormal speculative activity' and to 'continued decline...in the trade and profits available for investment in land'. Also important was 'the heavy fall in the value of land in the neighbourhood of Bombay and other large cities. Prospective buyers will not buy on a falling market. ${ }^{99}$ However, even as the report for 1924 noted that 'the reaction following the heavy speculative investment in properties is exhausted and normal conditions promise to be established', Bombay's land values remained depressed: 'the value of immovable properties...in Bombay has declined by 25.5 percent' ${ }^{100}$ A number of cases after 1920 considered precisely the question of how to calculate land values as they fluctuated, and how far speculative activity should be incorporated into such calculations.

In a case in 1923, for example, the government of Bombay had identified two pieces of land for compulsory acquisition in the suburb of Dadar. ${ }^{101}$ The claimant, Merwan

\footnotetext{
${ }^{96}$ City of Bombay Improvement Trust, Annual Report for 1921-22, Appendix O-2, Scheme 53, case 1, paras. 67, IOR, BL.

97 Ibid.

${ }^{98}$ V/24/3481, IOR. The Registration Department's Annual Report indicated that the average values of immoveable property in Bombay fell by 54.3 per cent in 1921, a slump which continued into the 1920 s.

${ }^{99}$ V/24/3482 IOR. Registration Department Annual Report for the Bombay Presidency, 1922.

${ }^{100}$ Ibid., 1924.

10125 Bom LR (1923) 1182, the Government of Bombay vs. Merwan Moondigar Aga. There were a number of disputes that debated how to deal with rising land values after the war. See, for instance, 24 Bom LR (1922).
} 
Moondigar Aga, had bought the two plots in 1912 for Rs 25,300 at Rs 4-4-0 per square yard. ${ }^{102}$ In 1919, he had an offer to sell at Rs 30 and another in 1920, Rs 42 per square yard. In light of the offers, the officer maintained that they were bona fide, but still only offers: 'by themselves they do not furnish the value of a finished transaction'. ${ }^{103}$ Instead, he was guided by sales in the neighbourhood, with the resultant valuation of Rs 18 per square yard for one plot and Rs 25 per square yard for the other. The judge, determined to go by neighbouring sales rather than offers, looked to a recent sale directly across from the land in question. There, the land had been sold at the height of the boom in 1920 at Rs 33 per square yard and the question was whether that could serve as a guide price for Merwan Aga's plot of land. The buyer, one Jamnadas, admitted to buying the land 'in the hope of reselling at a profit', although, unfortunately for him, the profit never came. ${ }^{104}$ The government's counsel contended that the sale was either a sham or of such a speculative nature that it should be ignored. However, the judge considered that 'a parcel of land... bought by a speculator in land with the object of re-selling it at a profit is no ground for disregarding the sale in compensation cases'. ${ }^{105}$ The previous owners had bought the land with this intention, as did Jamnadas, who had bought it from them. Thus, 'both vendors and purchasers were speculators'. But, the judge maintained, this was 'no ground for ignoring the transaction altogether'. Simply because the sale was speculative did not discredit it.

Counsel for the government of Bombay argued that the wave of speculation in 19191920 had resulted in spiralling land prices that could not be a gauge to calculating the 'market value' of land, which should be understood as its 'intrinsic value'. The claimant's counsel disputed this, arguing that 'market value' was something other than intrinsic value. Faced with this stalemate, the judge had to decide how far 'the element of rise in the price of land occasioned by speculation is to be taken into consideration'. ${ }^{106}$ Section 23 in the Land Acquisition Act of 1894 stipulated that 'market value' meant 'the value which a parcel of

\footnotetext{
471, The Government of Bombay v. N.H. Moos; 26 Bom LR (1924) 227, Government of Bombay v. Ismail Ahmed Hafiz Moosa; 28 Bom LR (1925) 714, The Land Acquisition Officer, Bandra v. Gulam Hussein Ahmad Gomajee.

${ }^{102}$ Four rupees and four annas. An anna was one sixteenth of a rupee.

${ }^{103} 25$ Bom LR (1923), 1183.

${ }^{104}$ Ibid., 1186.

${ }^{105}$ Ibid., 1187.

${ }^{106}$ Ibid., 1188.
} 
land would realise if sold in the market'. ${ }^{107}$ The seller must be willing and the purchaser must be prudent, that is, someone who makes the necessary inquiries as to the value of the land. Someone who carelessly makes an uninformed offer 'affords no test of market value'. The 'essential feature of market value', the judge determined, is 'the value that could be realised on a sale in the open market'. Whether 'dull or brisk' the market 'cannot be excluded from consideration' as 'there is nothing in the Land Acquisition Act which requires the Court to do so'. ${ }^{108}$ On the contrary, he noted, 'you cannot possibly ascertain the market value of a piece of land at a given time if you exclude from consideration the state of the market at that time.... The high rates prevailing in 1919 and the first half of 1920 cannot be ignored'. ${ }^{109}$

\section{Conclusion}

In the first decade of the Bombay Improvement Trust's activities, the intricate mathematical calculations brought to bear in the compensation awards of acquired land reflected an idea that the value of land could be calculated accurately and that it had an intrinsic value. In the early years of the Trust's operations, the special officers of the government overseeing land acquisition maintained that their methods should not encourage speculation. The hypothetical scheme was rejected for projecting unsubstantiated values, and plotting or offers of sales appeared as whimsical and subject to exploitation. Yet as the Trust's activities brought a swathe of new investors into the market, the idea that value could be decided objectively was difficult to sustain. The Trust wanted to encourage private investment but found it hard to manage what seemed to be an accelerating market in land. They wanted investors to buy the land north of the city, but not hoard it waiting for prices to go up. Criticisms of the Trust came from the wealthy landowners of the city and particularly from the Bombay municipal corporation who accused it of failing to solve the problems of urban development and of mismanaging and even exploiting the land market.

The period after the First World War brought a moment of great land speculation and a shift in the importance given to the intrinsic value of land. ${ }^{110}$ Judges deciding cases in compensation who had earlier argued strongly against incorporating rising land values into

\footnotetext{
${ }^{107}$ Ibid., 1189.

${ }^{108}$ Ibid.

${ }^{109}$ Ibid.

110 'Estate market, slump in Bombay and its causes', Times of India, 21 Jul. 1924.
} 
their calculations, increasingly argued that the speculative trend in the land market was central to the motivations of buyers and sellers and must now be figured in. Yet, as awards could be raised, so they could also be reduced when it was deemed the market had cooled off, which it did, in quite dramatic fashion after 1920: people reported properties that had earlier sold for Rs. 300,000 now only fetching Rs 50,000. The problems with land speculation continued: the professional speculators' profits from new developments, the high rents of landlords and the hoarding of land. The Trust and its officers were also perceived to have benefited from the rising price of land and were themselves accused of 'profiteering' from the auction of leases. ${ }^{111}$

The slump after 1920 did not prompt a return to the pre-war practices of valuation. Officials of the Trust now accepted as a matter of course that calculations should reflect the shifts in the market as investors would expect an enhanced return on an investment. Those who had profited through the War years sought to realise their material ambitions, in part, at least, through reinvesting those profits in urban property. With the Trust weakened, these ambitions dovetailed with broader shifts in approaches to the economy: the idea that the economy of which the land market was a part, was an entity that officials now saw as working independently of them. Moreover, the investor-speculators had also to accept risk as par for the course. Where between 1922 and 1925 people had been reluctant to acquire land, by 1926 they were, once again, 'feeling the temperature of the market'. ${ }^{112}$ With large amounts of land being made available, people were asking 'what the state of the land market is, and what its future promises to be'. As one correspondent observed: 'if a fair rate of interest on capital is shown, the public seems inclined once more to look favourably upon property as an investment'. ${ }^{113}$ The Trust's calculations were often for land that had only recently come into being and for which valuation was a creative fiction. In the early years, it was important for its officials to maintain this fiction through the rationality of the law and the science of mathematical projection. The attempt at certainty in these valuations faded after the mid-1920s.

\footnotetext{
111 'The right to profiteer', Times of India, 8 Feb. 1923.

112 'The land market in Bombay, possibilities of confidence re-appearing', Times of India, 6 Apr. 1926.

${ }^{113}$ Ibid.
} 
Scholars of urban environments have posited a close connection between urban expansion and capitalist speculation in land. In the case of Bombay, historians have argued that in the early twentieth century the land acquisition of the Bombay Improvement Trust was a key factor in rising land values. Yet what precisely its role was in shaping the land market and speculation has been unclear. Its systematising of tenures and laying out of plots certainly drew new investors in land which pushed forward a new phase in Bombay's capitalist land market. This article has suggested that what tied land acquisition by the Trust and private investment in land together was the role of court rulings on the methods by which the plots of land were valued. In a study of disputes around compensation for acquired land, it shows how the platform this created enabled people to forward competing claims around land values. The Trust's position was ambiguous: in leasing out plots it sought to manage the land market in an objective fashion. However, its ability to do so was limited both by such disputes around the 'market value' of any plot and by the growing idea that their awards must ultimately be shaped by the speculative trends of the market itself. 